\title{
Current state of biogas production in Croatia
}

\author{
Vlatka Petravić-Tominac ${ }^{1}$, Nikola Nastav², Mateja Buljubašić1 and Božidar Šantek ${ }^{1 *}$
}

\begin{abstract}
For biogas production, different renewable feedstocks, e.g., feces, manure, silage, industrial by-products, and municipal waste, can be used. Biogas production from various renewable feedstocks has positive socioeconomic and environmental impact. In Europe, biogas is mainly used for generating heat and electricity. It consists of methane ( $55-70 \%$ by volume), carbon dioxide (30-45\% by volume), and small amounts of other compounds. In some cases, biogas is upgraded to pure biomethane and utilized as vehicle fuel, instead of fossil fuels, thus reducing the emissions of greenhouse gases. Biomethane can also serve as a platform chemical in chemical and biochemical synthesis to produce value-added products. The additional positive effects of anaerobic digestion of animal manure and slurries are organic waste degradation, reducing odors, and pathogens. Digestate, obtained as a by-product of anaerobic digestion, is rich in nutrients and therefore is applied as fertilizer in agriculture. Biogas production in Croatia is mainly based on manure and by-products from agriculture, food industry, and slaughterhouses. The obtained biogas is mostly used for electricity and heat generation. Potential for large-scale biogas production in Croatia is still insufficiently used, although various renewable feedstocks are available. More rational and focused management of lignocellulosic residues, animal excrements, food processing by-products, and biodegradable fraction of municipal waste could contribute to the development of Croatian biogas sector. Biogas production in Croatia can be affected by the changes of animal breeding capacity due to the struggle to cope with the European Union (EU) standards and prices. Concerning large unused agricultural areas, great potential lies in their rational exploitation for fast-growing biomass, e.g., for energy crops or perennial grasses. This review will discuss the potential of biogas in the industrial and farming sector, current state of biogas production, and various key drivers and barriers influencing biogas production in Croatia.
\end{abstract}

Keywords: Anaerobic digestion, Biogas, Feedstocks, Renewable energy, Digestate

\section{Background}

The formation of biogas is a microbiological process that occurs naturally when organic materials (biomass) decompose in a humid atmosphere in the absence of air, but in the presence of the appropriate microorganisms. In nature, biogas is formed as marsh gas (or swamp gas) in the digestive tract of ruminants, in plants for wet composting, and in flooded rice fields $[1,2]$. Biogas can be produced in different types of plants: landfills, plants treating sewage, or anaerobic digestion plants. Properties of biogas, e.g., its chemical composition, energy content,

\footnotetext{
* Correspondence: bsantek@pbf.hr

'Laboratory for Biochemical Engineering, Industrial Microbiology and Malting and Brewing Technology, Department of Biochemical Engineering, Faculty of Food Technology and Biotechnology, University of Zagreb, Pierottijeva 6, Zagreb, Croatia

Full list of author information is available at the end of the article
}

or fuel equivalent, vary depending on its origin. Biogas consists mainly of methane (typically $55-70 \%$ by volume) and carbon dioxide (30-45\% by volume), but it also contains several impurities which are usually hydrogen sulfide (typically $50-2000 \mathrm{mg} / \mathrm{L}$ ), water vapor (saturated), oxygen (below $1 \%$ by volume), nitrogen (below $2 \%$ by volume), and various trace hydrocarbons (e.g., benzene up to $2.5 \mathrm{mg} / \mathrm{m}^{3}$ or toluene up to $11.8 \mathrm{mg} / \mathrm{m}^{3}$ ) [3]. Biogas composition depends on the substrate, as well as other factors $[4,5]$. Anaerobic digestion of agricultural residues, energy crops, and biodegradable industrial by-products is mentioned as a technology of increasing interest, capable of reducing the greenhouse gas (GHG) emissions and facilitating a sustainable development of energy supply [6]. Multiple benefits of anaerobic digestion are reflected at local, national, and even global scale. 
Biogas production by anaerobic digestion offers great advantages over other ways of bioenergy production. In fact, it is one of the most energy-efficient and environmentally friendly technologies for the bioenergy production $[2,5]$.

This paper presents an overview of feedstocks, anaerobic digestion, and design of anaerobic digestion plants, as well as possible applications of biogas produced by anaerobic digestion. The biogas sector is very diverse across Europe. It is well developed in Germany, Denmark, Austria, and Sweden, followed by the Netherlands, France, Spain, Italy, the UK, and Belgium $[5,7]$. The current state of biogas production in Croatia and its potential in the future will be discussed, as well as various obstacles preventing the faster development of biogas production sector.

\section{Biogas feedstocks and anaerobic digestion process}

A huge amount of organic solid raw materials (feedstocks) is generated through human activities. These feedstocks are available at low costs and can be used for biogas production. A wide range of organic raw materials can be stabilized by anaerobic digestion, and this variety of feedstocks can be classified into several groups: (1) feces, manure, and slurry from animal breeding; (2) silage and renewable lignocellulosic raw materials; (3) organic by-products from food industries and slaughterhouses; (4) biodegradable fraction of municipal solid waste (MSW), also called organic fraction of municipal solid waste (OMSW); and (5) microbial biomass. The largest potential for biogas production lies in lignocellulosic raw materials (residues) which contain three main structural constituents: cellulose $30-50 \%$, hemicellulose $20-40 \%$, and lignin $10-25 \%[8,9]$. They are available worldwide in huge amounts. Lignocellulosic residues are attractive feedstock for biogas production due to their high carbohydrate content. The use of lignocellulosic residues as feedstocks for biogas production is currently not often due to their recalcitrant structure which is the main challenge [10]. When lignocellulosic raw materials are used, the rate-limiting step in anaerobic digestion is hydrolysis. To degrade a recalcitrant structure of lignocellulosic feedstock and to increase the rate of biomass degradation and biogas yield, it is required to perform the appropriate pretreatment before anaerobic digestion $[6$, 11]. The goal of the pretreatment is to expose cellulose and hemicellulose to microbial breakdown. Pretreatment methods are generally classified into four main groups, i.e., physical, chemical, physicochemical, and biological. Although a variety of methods exist, not all of them are fully feasible for industrial scale [10-15].

The biogas yield mainly varies depending on the content of carbohydrates, proteins, and fats in these feedstocks $[4,5]$. The content of fats has the highest impact on the biogas yield compared to the protein or carbohydrate content in feedstocks. However, longer retention time in biogas production system is required for fat degradation due to their complex structure and degradation pathway. Carbohydrates and proteins have considerably higher degradation rates, but their biogas yields are much lower. The $\mathrm{C}: \mathrm{N}$ ratio during anaerobic digestion should be in the range of $15-30$, to avoid bioprocess failure because of ammonia accumulation.

In the biogas sector across Europe, there is a wide diversity regarding feedstocks [7]. EU countries have structured their financial incentives to favor different feedstocks, depending on national priorities, i.e., whether biogas production is primarily seen as a means of waste management (e.g., in the UK, over $80 \%$ of biogas is obtained from landfill and sewage sludge), as a means of generating renewable energy (e.g., in Germany, 93\% of biogas is obtained from agricultural crops (predominantly corn silage) and agricultural residues), or a combination of the two. Various feedstock combinations are used in other EU countries, depending on the specific circumstances, availability, and prices of individual feedstock. In the upcoming period, a stagnation of biogas production from landfill and sewage sludge is expected. In the same time, production from agricultural feedstocks will increase. In different EU countries, situation depends on various factors, such as attractiveness of investing (building new biogas plants or only rejuvenating the existing plants), guaranteed "feed-in tariff" price which is considerably higher than that of electricity generated from other sources, the national goal to use a certain percent of livestock manure for biogas production, or national action plans regarding renewable energy. Regarding biogas production, each country has its own specific obstacles to overcome [7].

Anaerobic digestion is performed by a complex consortium of microorganisms, and the bioprocess consists of four phases [11]: hydrolysis, acidogenesis, acetogenesis, and methanogenesis. These phases occur simultaneously, and different groups of bacteria collaborate by forming an anaerobic substrate chain where the products of one group will be the substrates of another group. During hydrolysis, extracellular enzymes of hydrolytic microorganisms decompose complex organic matter into simple soluble molecules, i.e., complex carbohydrates, fats, and proteins are hydrolyzed into sugars, fatty acids, and amino acids. Acidogenic bacteria (acidogens) further convert the simple soluble molecules into a mixture of volatile fatty acids (VFAs) and other minor products such as alcohols. Acetogenic bacteria (acetogens) then convert the VFAs into acetic acid (acetate), $\mathrm{CO}_{2}$, and hydrogen. From these substrates, methanogenic bacteria (methanogens) produce biogas in the last 
step called methanogenesis. Methanogenic bacteria produce methane from acetate or hydrogen and carbon dioxide. Only few species are able to degrade acetate into $\mathrm{CH}_{4}$ and $\mathrm{CO}_{2}$ (e.g., Methanosarcina barkeri and Methanococcus mazei), whereas all methanogenic bacteria are able to form methane from $\mathrm{CO}_{2}$ and hydrogen. The performance of the anaerobic digestion depends both on the characteristics of feedstock and the activity of the microorganisms involved in different degradation steps. The potential imbalance between microbial groups can affect the overall reaction rate or cause accumulation of inhibitors, which may lead to the failure of the anaerobic digestion [4, 5]. Among the four microbial groups, methanogens have the slowest growth rate. They are the most sensitive to changes of environmental conditions (e.g., temperature, $\mathrm{pH}$, presence of inhibitors), and therefore, methanogenesis is a rate-limiting step in anaerobic digestion. Anaerobic digestion in the biogas production systems is most often conducted at mesophilic $\left(35-42^{\circ} \mathrm{C}\right)$ or thermophilic $\left(45-60^{\circ} \mathrm{C}\right)$ conditions. Maintaining the constant optimal temperature is important during largescale bioprocess because temperature changes or fluctuations negatively affect biogas production $[4,5]$. The $\mathrm{pH}$ interval for methane synthesis is relatively narrow (about 6.5-8.5) with an optimum of $\mathrm{pH} 7.0-8.0$. There is a strong inhibition at $\mathrm{pH}$ values below 6.0 or above 8.5. Due to protein degradation, ammonia is accumulated and the $\mathrm{pH}$ value increases, while VFA accumulation decreases the $\mathrm{pH}$ value. The inhibition caused by VFAs is more pronounced at $\mathrm{pH}$ values close to or below $\mathrm{pH}$ of 7 [4]. Macronutrients (carbon $(\mathrm{C})$, nitrogen $(\mathrm{N})$, phosphorus $(\mathrm{P})$, and sulfur $(\mathrm{S})$ ) and micronutrients are required for the growth and function of microorganisms. Microbial biomass growth in anaerobic digestion is low and therefore is a nutrient ratio of $\mathrm{C}: \mathrm{N}: \mathrm{P}: \mathrm{S}=600: 15: 5: 1$ regarded as sufficient. Micronutrients (iron, nickel, cobalt, selenium, molybdenum, and tungsten) are necessary for the growth of microorganisms and have to be added in some cases, e.g., if energy crops are used for biogas production as the only substrate. Nickel is generally required for methane synthesis in all methanogenic bacteria. Generally, the sufficient concentrations of micronutrients are very low (0.05-0.06 $\mathrm{mg} / \mathrm{L}$ ), with the exception of iron which is required in higher concentration $(1-10 \mathrm{mg} / \mathrm{L})$. The addition of manure reduces the lack of micronutrients. But even in bioprocesses where a content of manure is 50\%, micronutrient addition can increase the rate of anaerobic digestion $[4,5]$.

\section{Biogas plants and biogas applications}

Biogas plants are classified based on the type of feedstocks, applied technology, and plant size. Anaerobic digestion can take place in domestic, farming, and industrial scale. Domestic biogas plants (bioreactor volume of a few cubic meters) are mostly used in developing countries for direct biogas combustion in household stoves and gas lamps. The most common bioreactor type, which is used in the small farm plants, is a vertical tank generally made of concrete. It is equipped with a flexible membrane and light roof making it possible to be used as bioreactor and gas-storage tank simultaneously. The average bioreactor volume in the small farm plants is typically from a couple of hundreds to a thousand cubic meters [16, 17]. According to Mao et al. [18], there are three different types of industrial anaerobic digestion bioreactors (volume of a few hundreds to several thousands of cubic meters): conventional anaerobic bioreactors (e.g., anaerobic sequencing batch bioreactor, continuous stirred-tank bioreactor), sludge retention bioreactors (e.g., anaerobic contact reactor, internal circulation reactor), and anaerobic membrane reactors (e.g., anaerobic filter reactor, anaerobic fluidized bed reactor). However, the vertical continuous stirred-tank reactor (CSTR) is the most common bioreactor type (nearly $90 \%$ of installed bioreactors) for wet anaerobic digestion (total solid concentration is below $15 \% \mathrm{w} / \mathrm{w}$ ) in Germany [19]. CSTR is often covered with a gas-tight single or double membrane roof for storing the gas in the bioreactor top before utilization. Mixing is required in the CSTR to bring microorganisms in contact with the substrates, to enable the gas bubbles upflow, and to maintain constant optimal temperature in the bioreactor. To prevent sedimentation and swimming layers, up to four stirrers are installed, depending on the bioreactor volume and substrate type. Slow-rotating paddle stirrers with a horizontal, vertical, or diagonal axis and largescale paddles are preferred for bioreactors operating at high total solid contents $(>15 \% \mathrm{w} / \mathrm{w})$. In this case, the motor is located outside the bioreactor, while axial stirrers are mounted on shafts that are centrally installed on the bioreactor ceiling. It allows a steady stream in the bioreactor that flows from the bottom up to the walls which brings good homogenization of solid substrates with manure or recycled process water. However, horizontal plug-flow bioreactor and bioreactors with hydraulic mixing by pumps are also used for anaerobic digestion. The anaerobic digestion in bioreactor can be performed in batch, fed batch, repeated batch, or continuous mode [19].

Biogas formed by anaerobic digestion consists mainly of methane and carbon dioxide as well as minor amounts of other compounds: nitrogen which originates from air saturated in the influent, vapor water derived from medium evaporation, oxygen which is entering the process from the influent substrate or leakages, hydrogen sulfide produced from the reduction of sulfate contained in some wastestreams, ammonia originating from hydrolysis of proteins or urine, and hydrocarbons 
and siloxanes. There are various reasons for the removal of these minor compounds: hydrogen sulfide and ammonia are toxic and extremely corrosive, damaging the combined heat and power (CHP) unit and metal parts via the emission of $\mathrm{SO}_{2}$ from combustion [20]. There are two types of biogas treatment-biogas cleaning as first, and biogas upgrading as a second treatment, when necessary. Biogas cleaning includes the removal of various harmful and/or toxic compounds, but it is mainly focused on the $\mathrm{H}_{2} \mathrm{~S}$ removal. The aim of biogas upgrading is to increase its low calorific value, i.e., to convert it to a higher fuel standard. During the upgrading process, the $\mathrm{CO}_{2}$ contained in the raw biogas is either removed or converted to methane by reaction with $\mathrm{H}_{2}$ [20]. When biogas is purified to specifications similar to natural gas, the final product is called biomethane (containing > 95\% of methane, depending on national regulations) [20,21]. Several technologies (e.g., water, organic, or chemical scrubbing; adsorption with pressure swing technology with (or without) vaccum; membrane and cryogenic separation) are available for biogas cleaning and upgrading, as reviewed in literature [22-26].
Potential applications of biogas produced by anaerobic digestion are shown in Fig. 1. Biogas is an alternative to fossil fuels. In Europe, biogas is mainly used for the production of heat and electricity and in some cases is upgraded to biomethane and utilized in natural gas grid or as vehicle fuel. The production of electricity and capturing the process heat at the same time is called cogeneration, and it is performed on the combined heat and power (CHP) engines. A part of the heat obtained at the CHP is used for the heating of biogas plant itself, and the remaining heat can be distributed in the district heating systems. From year 2000 to 2014, total globally produced electricity from biogas (approx. 80.1 TWh) on the electricity-only units and CHP units has increased 3.7 and 10 times, respectively [27]. In Europe, there is recently an increasing number of large-scale biogas plants applying biogas-upgrading technology to purify biogas into biomethane, which is then injected into the natural gas grid or used as vehicle fuel instead of fossil fuels $[20,21]$. This reduces the emissions of greenhouse gases and thus prevents climate change [23-26]. Furthermore, biomethane can be used as a platform

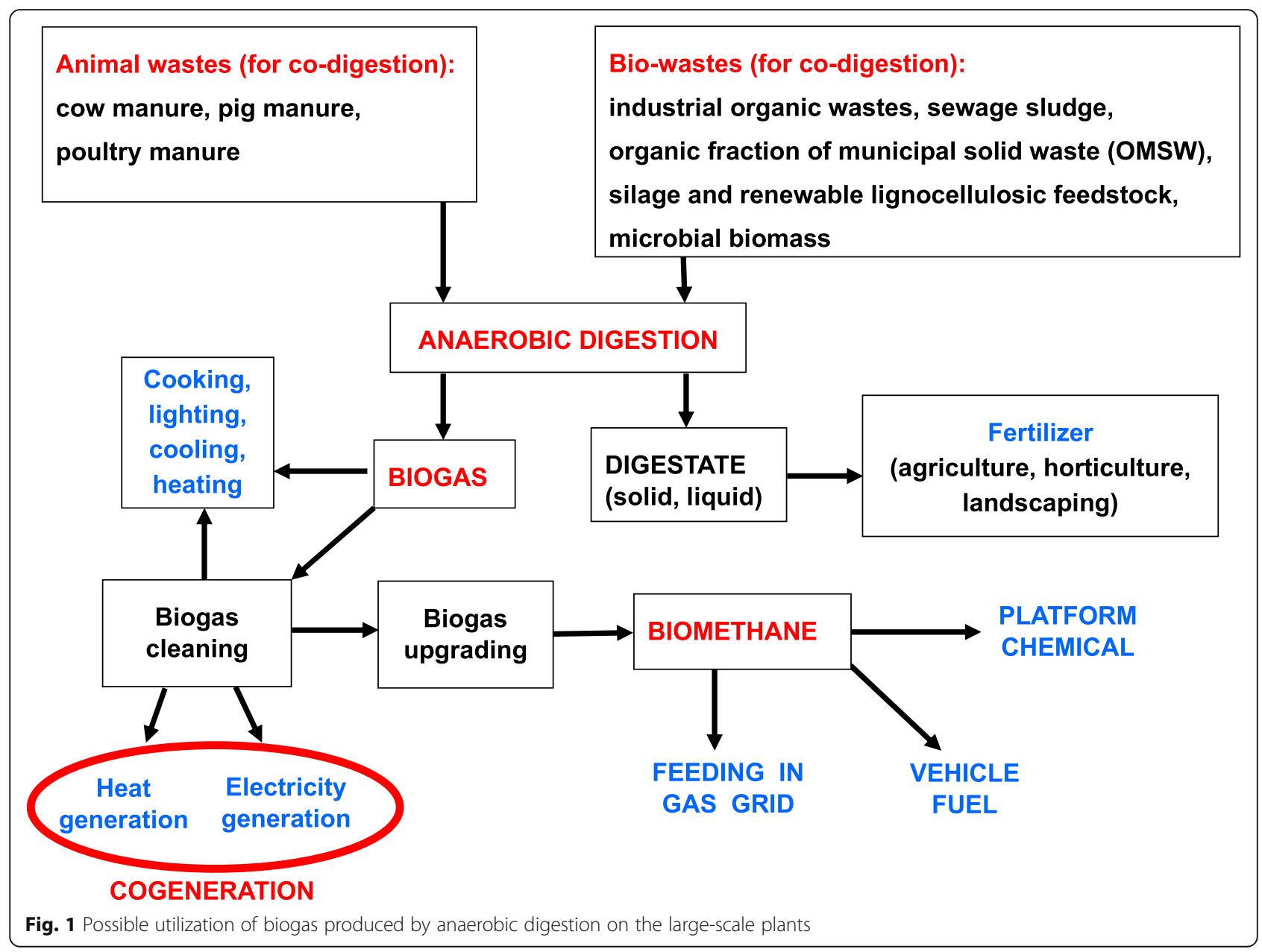


chemical in various chemical and biochemical synthetic processes [28-30]. An example of biogas utilization is biomethanol production in the advanced biofuel plant BioMCN. Biomethanol can be blended with gasoline or used for the production of bio-methyl tertiary butyl ether (bio-MTBE), bio-dimethyl ether (bio-DME), or synthetic biofuels. In 2017, BioMCN started to use $\mathrm{CO}_{2}$, as by-product of biogas production, for biomethanol production [31]. The secondary product of the anaerobic digestion, the so-called digestate, can be used as a fertilizer due to its excellent fertilizing properties. It is efficient and environmentally friendly, and can compete with mineral fertilizers. Digestate contains all nutrients and micronutrients necessary for modern farming, including nitrogen, phosphorus, and potassium. Organic matter in digestate can build up the humus content in the soil, which is an additional benefit. Animal and plant pathogens are significantly reduced during anaerobic digestion and in most cases are eradicated, due to the technical and thermal pretreatment of feedstocks and the conditions in the bioreactor. Seeds of invasive weeds, which may be present in the feedstock, are inactivated during anaerobic digestion. Compared with raw organic material used as feedstock for anaerobic digestion, unpleasant odors and dangerous gases are also minimized by anaerobic digestion. Therefore, digestate is a much safer fertilizer than nutrients from raw organic materials and it can increase bioprocess profitability carried out in large scale. If farmers build a digester to treat waste produced in their farms, they can produce digestate for their own agricultural land and even sell a part of digestate as an additional income source [32,33]. It is also important to stress the positive socioeconomic impact of biogas production on the enlarged job opportunities [34].

\section{Biogas production in Croatia-problems and potential solutions}

In Croatia, the first biogas power plant using renewable feedstocks with cogeneration unit, to produce heat and electricity, started to operate in 2009 with installed power of $1 \mathrm{MW}$. Five years later (in 2013), 10 biogas power plants already operated in Croatia. The highest increase of the number of biogas power plants was observed in the period of 2015-2018, when 20 new biogas power plants started to operate. In 2017, 19 new electricity purchase agreements with Croatian Energy Market Operator (HROTE) [35] were signed, and therefore, it is expected that the number of biogas plants in Croatia will be increased in the near future. However, investors have to acquire the status of privileged producer (HROTE has selected them as lowest bidder in a public tender) to deliver electricity into the national grid system. In defined time period (1-4 years), they have to regulate their status according to the voltage of distribution system (higher voltage of the distribution system is correlated with longer period, e.g., 4 years for the electricity distribution system $\geq 30 \mathrm{kV}$ ) [36].

In 2018, there were 38 operating biogas plants that had contracts for electricity production with HROTE [35]. The highest installed biogas power plant of 2.5 MW, located in Zagreb (the capital of Croatia), is classified in the category of "plants operating with landfill gas and gas from wastewater treatment plants" and represents $5.78 \%$ of the total power obtained from the biogas in Croatia. The rest $94.22 \%$ (i.e., $40.732 \mathrm{MW}$ ) is produced in other 37 biogas power plants, which apply anaerobic digestion technology. Among these, 6 biogas power plants are of installed power less than $0.5 \mathrm{MW}$, and 6 plants are between 0.5 and $1 \mathrm{MW}$. Power plants with installed capacity of $1 \mathrm{MW}$ are predominant (a total of 15). Four plants belong to a group between 1 and 2 $\mathrm{MW}$, and the 6 largest biogas plants have an installed power of $2 \mathrm{MW}$. In 2018, biogas power plants generated altogether $316.5 \mathrm{GWh}$, representing $12.75 \%$ of the total electricity production from all renewable resources (e.g., wind-, solar-, or hydro-power, biomass, geothermal power; a total of $2482.5 \mathrm{GWh}$ ). In the last 5 years (20142018), the total electricity production on the biogas power plants was constantly increased by the average annual rate of approximately $10 \%$ [35].

The most often used medium for biogas production in Croatia consists of manure $(50-60 \%$, mainly obtained from cow breeding but also from pigs, poultry, or their combinations), corn (or grass) silage (25-35\%), and other available biodegradable feedstocks (5-25\%, e.g., food waste, spent brewer's yeast, wastewater sludge, fats, garden waste). However, the medium composition for biogas production strongly depends on the accessibility of raw materials in the biogas plants vicinity. Most Croatian biogas plants are located in the continental part of Croatia due to the accessibility of feedstocks for biogas production. However, only three biogas power plants are planned to be constructed on the Croatian Adriatic coast, mostly in the surrounding of the largest coastal cities [35, 37].

Because of good geographical location, and environmental and climatic conditions, Croatia has a great potential for agriculture and forestry. Therefore, a large amount of biodegradable residues from agriculture, foresty, wood processing, and food industry are available and they can become a valuable feedstock for biogas (or biomethane) production [38, 39]. The most abundant crops in the agricultural production of Croatia are corn and wheat, followed by other crops typical for this area, such as barley, sugar beet, fruits, vegetables, and oilseed crops [39]. Therefore, the most common lignocellulosic residues of agricultural origin available in Croatia are byproducts from corn and wheat breeding, i.e., corn stover, corn cobs, corn husk, and wheat straw. Residues of other important crops (barley straw, leaf rosette of sugar beet, 
i.e., top and leaves of sugar beets) are also available in significant annual amounts.

For illustration, in the last 5 years, an average production of $809.78 \mathrm{kt}$ of wheat was annually obtained, i.e., an average of 157,162.0 ha, with an average yield of $5.22 \mathrm{t}$. Harvest indexes for various types of wheat, published for Croatia and neighboring countries, range from 35.8 to $52.1 \%$, i.e., 35.8 to $52.1 \mathrm{~kg}$ of grain per $100 \mathrm{~kg}$ of total crop weight [40, 41]. The mass of the produced wheat grain is roughly equal to the mass of residual straw. Wheat straw can be used for biogas production due to the fact that it is a rich source of carbohydrates. Therefore, it has relatively high potential for biogas production (the range of $200-300 \mathrm{~m}^{3} / \mathrm{t}$ of wheat straw), but mechanical (e.g., milling or grinding) and chemical (e.g., acid or alkaline) pretreatments are required to achieve the highest biogas yields $[42,43]$. Therefore, economic aspects of biogas production together with available quantities of wheat straw in a particular region have to be taken into consideration. The total corn production for the mentioned period was $1868.92 \mathrm{kt}$ on the harvest area of 260818.6 ha, with a yield of $7.18 \mathrm{t} / \mathrm{ha}$. Harvest indexes for various corn types in Croatia and neighboring countries range from 40 to around $80 \%$ [44, 45]. Calculated with an average harvest index of about $60 \%$, the obtained amount of corn residues is around $40 \%$, i.e., around $1245.95 \mathrm{kt}$ per year, i.e., $4.79 \mathrm{t} / \mathrm{ha}$. If only $40-50 \%$ of corn residues would be used for biogas production, it is possible to obtain cca 99.6 millions $\mathrm{m}^{3}$ of biogas per year. The potential of biogas production from corn residues is in the range of $180-220 \mathrm{~m}^{3} / \mathrm{t}$ of feedstock. It has to be pointed out that corn residues, similar to wheat straw, should be subjected to the appropriate pretreatment to become more suitable for biogas production [42, 46, 47]. Lignocellulosic residues from other cultivated crops can also be considered as a potential feedstock for biogas production. However, it should be borne in mind that a part of these residues are already being used for other economically justified purposes, such as feed. In the last 5 years, corn silage production was on the average of $1070.94 \mathrm{kt} /$ year at $30,067.8 \mathrm{ha}$, with a yield of $35.52 \mathrm{t} / \mathrm{ha}$. Corn silage is one of the most valuable forages for ruminant livestock, but in Croatia, it also serves as an important feedstock for biogas production. Its potential for biogas production is in the range of $250-350 \mathrm{~m}^{3} / \mathrm{t}$ of silage $[42,46]$.

Although agricultural residues can be used to produce energy, the agricultural potential of Croatia is still not sufficiently exploited. Unfortunately, about a half of the cultivated land is not used appropriately [38]. Concerning large unused agricultural areas, great potential lies in their rational exploitation for growing biomass, e.g., for energy crops or perennial grasses [48, 49]. Energy crop is a lowcost and low-maintenance plant used for biofuel production. After a perennial grass is established, the major expenses are for nitrogen fertilizers and harvest. These plants can grow in marginal and erosive soils and respond to nitrogen fertilization with remarkable increase in the biomass yield. Switchgrass (Panicum virgatum) and grass Miscanthus are good examples of these crops [49, 50]. Based on experiences with energy cultures from foreign countries, there were some experiments conducted on the introduction of Panicum virgatum and Miscanthus $x$ giganteus in Croatia. Since the first results were successful, these plants can also be considered as the future feedstock for biogas production [51-53].

A smaller part of forestry and wood residues in Croatia is used in the energy production for the needs of wood processing industry, and most of it is left in the forests or disposed of at landfills. Beech is the most treated wood type in Croatia, followed by oak and other types of wood (ash, poplar, etc.) which are processed to a much lesser extent $[54,55]$. Therefore, processing residues originating from beech and oak are mostly available. Wood residues could be used as biogas feedstock in parts of Croatia with a developed wood industry, but they have to be pretreated to become more suitable for use in the biogas production.

Animal breeding in Croatia generates large quantities of residues in the form of excrements (feces and urine) which can be disposed of by anaerobic digestion to serve as a valuable feedstock in the same time. Struggle to cope with the EU standards and prices could lower the capacity of animal breeding as well as biogas production [38]. The last 5-year average production of cattle, pigs, and poultry was $443,600,1,143,400$, and 10,013,800 heads of animals, respectively, showing that livestock and poultry production is relatively stable. The potential of cattle and pig manure for biogas production is in the range of $160-220 \mathrm{~m}^{3} / \mathrm{t}$ of substrate, and for poultry manure, it is slightly higher $\left(180-240 \mathrm{~m}^{3} / \mathrm{t}\right)[42,43,47,56-58]$.

Food processing industries also generate by-products, and their amounts depend on the industry and applied technology (e.g., 50\% of the processed fruit remains after juice production or $30 \%$ of the chicken's weight that is not suitable for human consumption remains after slaughtering and meat processing steps in poultry industry) [5]. Given the developed food industry in Croatia, the wider application of the generated by-products as biogas feedstock might be considered.

Some of the Croatian biogas plants use spent brewer's yeast as a feedstock. It is obtained in huge amounts as a byproduct in breweries all around the world. Most of it is usually sold after thermal inactivation as a cheap feed additive [59], but such use is at the margin of profitability. Due to transport costs, breweries sometimes give spent yeast free of charge to closely located distilleries and feed production facilities. On the other hand, instead of considering the spent brewer's yeast as an industrial by-product, it can be used as a feedstock for biogas production. 
According to the composition estimation for mixed municipal waste in Croatia [60], it contains around $60 \%$ of biodegradable waste (i.e., $30.9 \%$ of kitchen waste, $23.2 \%$ of paper and cardboard, $5.7 \%$ of garden waste, $1.0 \%$ of wood) which could be used as a biogas feedstock. Total quantity of produced municipal waste in 2015 was $1653.92 \mathrm{kt}$ (or $386 \mathrm{~kg}$ per capita). In Croatia, a mild growth of municipal waste is expected, from the current 1650.00 to about $2000.00 \mathrm{kt} /$ year in 2030. The decrease of the total quantities of produced municipal waste by $5 \%$, as well as separate collection of $40 \%$ of mass of produced bio-waste constituent in municipal waste, is among the waste management goals that need to be met by 2022 according to the Croatian government documents [60]. Biodegradable content of municipal waste $(\mathrm{BCMW})$ can be also considered as a substrate for biogas production because of biogas yield in the range of $110-150 \mathrm{~m}^{3} / \mathrm{t}$ of substrate. However, the potential of biogas production from BCMW depends on its accessibility (usually only $30 \%$ of BCMW ended on the biogas plants) for biogas production [42]. Other planned measures, which are also prerequisites for further development of the biogas sector in Croatia, are continuous educative and informative activities, as well as the improvement of the waste management information system, supervision, and administrative procedures in waste management.

The biogas produced by anaerobic digestion in Croatia is usually used for electricity and heat production. In Croatia, feed-in tariff (FiT) support scheme for electricity production from renewable energy sources (RES) is used. The Croatian electricity producer from RES has to sign the Electricity Purchase Agreement with Croatian Energy Market Operator (HROTE) for the standard period of 12 years to be able to deliver electricity into the national distribution system. The new scheme of FiT was introduced on January 1, 2016. It is based on the tendering procedure through which a premium tariff and a guaranteed feed-in tariff for biogas plants of less than $500 \mathrm{~kW}$ are allocated. Privileged producers of electricity from RES selected by HROTE as the lowest bidder in a public tender could receive a premium on the top of electricity price sold on the market. HROTE issues a call for tenders at least once a year, provided quotas for the support of certain technologies of renewable energies [61]. The amount of the premium tariff (PTi), which is expressed in HRK/kWh, is obtained as a difference between the reference value of electric energy (RV; which was defined in the contract between HROTE and the privileged producer) and the reference market price ( $\mathrm{RTi}$ ) in the accounting period. The calculation of premium tariff amount is done as follows:

$$
\mathrm{PTi}=\mathrm{RV}-\mathrm{RTi}
$$

If the calculated value of the premium tariff (PTi) is negative, the amount of the premium tariff is zero. The reference value of electric energy (RV) is adjusted every year, and the maximum reference value of electric energy is determined by HROTE based on the methodology of reference values of electricity price defined by the law [61].

EU (Croatia as member state) has developed and utilized different RES in order to reduce $\mathrm{CO}_{2}$ emission and its impact on the environment. The new EU directive 2018/2001 defines that by 2030, the RES content in the total energy consumption has to be at least $32 \%$ with a clause for a possible upwards revision by 2023. Data available for Croatia show that RES participates with $28 \%$ of total energy consumption, but the hydro-power has the major portion of RES in Croatia. If hydro-power will be excluded from RES, the total energy consumption from RES will be reduced to $5.8 \%$. In last few years in Croatia, the development of biogas sector was observed through the increased number of operating inland biogas plants. Therefore, the biogas content in the total electricity production in 2018 was enlarged at $12.75 \%$ from all available RES [35]. Recently, the Croation government is issued the new strategic document for the development of energy sector in Croatia till 2030 with projections on the 2050. It is in accordance with the new EU directive 2018/2001 [62]. In this document, it is planned that Croatia will increase electricity production from wind and solar power through the new plants construction. For example, one scenario is based on the increase of wind power plant capacities on the 1.600 MW till 2030 and $3.700 \mathrm{MW}$ in 2050, respectively. It represents annually the average of $110 \mathrm{MW}$ of new capacities for electricity production from wind power, but the current annual dynamic of new installations is only $50 \mathrm{MW}$. In the same time, new installations of solar power plants of $1.000 \mathrm{MW}$ are planned till 2030 and total installed capacity of solar power plants of 3.800 MW till 2050, respectively. Although Croatia has great potential in solar and wind power, the construction of these new plants is closely related to the significant increase of investment in the Croatian energy sector. Therefore, it is questionable if this plan could be fully executed in the defined time frame. On the other hand, the production of biofuels (e.g., biomethane, bioethanol, and biodiesel) from RES is restricted to only 7\% of total energy production in Croatia which is not an encouragement for further investment and development of biofuels production. According to the new strategic document, the purification of biogas into biomethane is planned and it could be an impulse for further development of the biogas sector in Croatia. However, environmental and social benefits of biogas production in rural regions should not be neglected. Therefore, the communication between professional organizations and state bodies related to biogas has to be further improved. Another 
important factor is the dissemination of information to potential investors as well as to farmers, general community, and through the education system to increase the knowledge of potentials of biogas usage in accordance with the Decision on the adoption of the Waste Management Plan of the Republic of Croatia for the period 2017-2022 [59]. It has to be pointed out that the gas infrastructure is also important for the development of biogas sector, e.g., (1) availability of gas or biogas pipelines; (2) existing gas storage (buffers); (3) infrastructure for natural gas, compressed natural gas (CNG), or liquefied natural gas (LNG) for vehicles; and (4) gas quality. Although biogas processing to biomethane is planned in Croatia, it is not yet realized as a prerequirement for biomethane injection in natural gas grid or utilization as a transport fuel. Biomethane is not included in the system of subventions (like bioethanol or biodiesel), and therefore, support schemes have to be established and incorporated in Croatian biogas legislatives [38, 42].

The development of biogas sector brings a number of new jobs on biogas plant itself, but also in the cooperatives producing raw materials for the biogas production. A practical guide to the basic legislation and procedures regarding energy production from waste in Central, Eastern, and Southeastern Europe can be found in literature [63].

Farmers are usually poorly informed about the financial benefits of digestate as well as the advantages of digestate compared to the mineral fertilizers, and hesitate about spreading them on their land. Therefore, education is required on the advantages of digestate and the adequate management of local resources to build confidence on its use.

Croatia has a good feedstock potential as a driving force for biogas development to be used for biogas/biomethane production. The availability of agricultural residues in certain regions should be taken into account. Barriers related to the access to the suitable by-product streams as well as the treatment of biogas by-products still exist, because of the lack of knowledge and expertise among potential investors, farmers, and producers.

Although there is a significant amount of agricultural residues, which represents an environmental problem, its organized collection for biogas, as well as other possible products, is still missing. More rational exploitation of unused land for growing biomass is required, e.g., for energy crops or perennial grasses. Efficient measures to maintain animal breeding capacities should also be taken, as residues resulting from animal breeding and meet processing facilities are important feedstock for biogas production.

\section{Conclusions}

Various renewable feedstocks for large-scale biogas production are available in Croatia, but the potential has been underutilized so far. Biogas production in Croatia is predominantly based on manure and by-products from agriculture, slaughterhouses, and food industry. With better land use and the development of the food industry, the amount of agricultural residues and by-products generated by food processing could increase. By directing and encouraging the use of these by-products for the production of biogas, it is possible to encourage a faster development of biogas production in Croatia.

The biogas produced in Croatia is mostly used for electricity and heat production on the cogeneration units. Aside from producing biogas as a renewable fuel, the additional positive effects of anaerobic digestion of animal manure and slurries are organic waste degradation, reducing odors and pathogens, and possibility of digestate use as a by-product rich in nutrients that can be used to fertilize agricultural land.

Better communication between professional organizations and state bodies related to the area of production, distribution, and application of biogas is necessary. Additional efforts should be taken to spread the information on biogas production by anaerobic digestion and its positive socioeconomic and environmental impacts.

\section{Abbreviations}

BCMW: Biodegradable content of municipal waste; Bio MTBE: Bio-methyl tertiary butyl ether; Bio-DME: Bio-dimethyl ether; C:N ratio: Carbon to nitrogen ratio; CHP unit: Combined heat and power unit; CNG: Compressed natural gas; CSTR: Continuous stirred-tank reactor; FiT: Feed-in tariff; GHG: Greenhouse gases; HROTE: Croatian Energy Market Operator; LNG: Liquefied natural gas; MSW: Municipal solid waste; OMSW: Organic fraction of municipal solid waste; RES: Renewable energy sources; VFAs: Volatile fatty acids

\section{Acknowledgements}

Not applicable

\section{Authors' contributions}

The authors have read and approved the final manuscript.

\section{Funding}

This work was supported by the project Phoenix (H2020-MSCA-RISE project no. 690925) and the project "Sustainable production of biochemicals from waste lignocellulose containing feedstocks" (Croatian Science Foundation No. 9717)

\section{Availability of data and materials}

Not applicable

Ethics approval and consent to participate

Not applicable

Consent for publication

Not applicable

\section{Competing interests}

The authors declare that they have no competing interests.

\section{Author details}

'Laboratory for Biochemical Engineering, Industrial Microbiology and Malting and Brewing Technology, Department of Biochemical Engineering, Faculty of Food Technology and Biotechnology, University of Zagreb, Pierottijeva 6, Zagreb, Croatia. ${ }^{2}$ Agrokor - Energija d.o.o., Trg Dražena Petrovića 3, Zagreb, Croatia. 
Received: 21 February 2019 Accepted: 24 January 2020 Published online: 07 February 2020

\section{References}

1. Salvi O, Chaubet C, Evanno S (2012) Improving the safety of biogas production in Europe. Revista de Ingeniería 37:57-65

2. Deublein D, Steinhauser A (2008) Biogas from Waste and Renewable Resources. An introduction. WILEY-VCH Verlag GmbH \& Co. KGaA, Weinheim.

3. Chattopadhyay S, Mukerji A, Sen R (2009) Biofuels. In: Nigam PS, Pandey, A. (eds) Biotechnology for agro-industrial residues utilisation. Springer Netherlands, 61-76.

4. Weiland P (2010) Biogas production: Current state and perspectives. Appl Microbiol Biotechnol 85(4):849-860. https://doi.org/10.1007/s00253-0092246-7

5. Horváth SI, Tabatabaei M, Karimi K, Kumar R (2016) Recent updates on biogas production - a review. BRJ 3(2):394-402. doi: 10.18331/BRJ2016.3.2.4.

6. Kusch S, Morar MV (2009) Integration of lignocellulosic biomass into renewable energy generation concepts. ProEnvironment 2:32-37

7. Flach B, Lieberz S, Rossetti A, Phillips S (2017) EU-28 Biofuels Annual 2017, GAIN Report Number: NL7015. Washington, DC, USA: USDA Foreign Agricultural Service. https://gain.fas.usda.gov/Recent\%20GAIN\%2 OPublications/Biofuels\%20Annual_The\%20Hague_EU-28_6-19-2017.pdf. Accessed 20 May 2019.

8. Sluiter JB, Ruiz RO, Scarlata CJ, Sluiter AD, Templeton DW (2010) Compositional analysis of lignocellulosic feedstocks. 1. Review and description of methods. J Agric Food Chem 58:9043-9053. https://doi.org/ 10.1021/jf1008023

9. Zhao X, Zhang L, Liu D (2012) Biomass recalcitrance. Part I: the chemical compositions and physical structures affecting the enzymatic hydrolysis of lignocellulose. Biofuels Bioprod Biorefin 6(4):465-482. https://doi.org/10. 1002/bbb.1331

10. Hendriks ATWM, Zeeman G (2009) Pretreatments to enhance the digestibility of lignocellulosic biomass. Bioresour Technol 100(1):10-18. https://doi.org/10.1016/j.biortech.2008.05.027

11. Zheng Y, Zhao J, Xu F, Li Y (2014) Pretreatment of lignocellulosic biomass for enhanced biogas production. Prog Energy Combust Sci 42:35-53. https://doi.org/10.1016/j.pecs.2014.01.001

12. Taherzadeh MJ, Karimi K (2008) Pretreatment of lignocellulosic wastes to improve ethanol and biogas production: A review. Int J Mol Sci 9(9):16211651. https://doi.org/10.3390/ijms9091621

13. Galbe M, Zacchi G (2012) Pretreatment: The key to efficient utilization of lignocellulosic materials. Biomass Bioenergy 46:70-78. https://doi.org/10. 1016/j.biombioe.2012.03.026

14. Bušić A, Marđetko N, Kundas S, Morzak G, Belskaya H, Ivančić Šantek M, Komes D, Novak S, Šantek B (2018) Bioethanol production from renewable raw materials and its separation and purification: A review. Food Technol Biotechnol 56(3):289-311. https://doi.org/10.17113/ftb.56.03.18.5546

15. Padrino B, Lara-Serrano M, Morales-delaRosa S, Campos-Martín JM, García Fierro JL, Martínez F, Melero JA, Puyol D (2018) Resource recovery potential from lignocellulosic feedstock upon lysis with ionic liquids. Front Bioeng Biotechnol 6:119. https://doi.org/10.3389/fbioe.2018.00119

16. Bojesen M, Boerboom L, Skov-Petersen H (2015) Towards a sustainable capacity expansion of the Danish biogas sector. Land Use Policy 42:264277. https://doi.org/10.1016/j.landusepol.2014.07.022

17. Vögeli Y, Lohri CR, Gallardo A, Diener S, Zurbrügg C (2014) Anaerobic digestion of biowaste in developing countries: Practical information and case studies. Swiss Federal Institute of Aquatic Science and Technology (Eawag), Dübendorf, Switzerland. https://www.eawag.ch/fileadmin/ Domain1/Abteilungen/sandec/publikationen/SWM/Anaerobic_Digestion/ biowaste.pdf. Accessed 27 Apr 2019.

18. Mao C, Feng $Y$, Wang $X$, Ren $G$ (2015) Review on research achievements of biogas from anaerobic digestion. Renew Sust Energ Rev 45:540-555. https:// doi.org/10.1016/j.rser.2015.02.032

19. Gemmeke B, Rieger C, Weiland P (2009) Biogas-Messprogramm II, 6 Biogasanlagen im Vergleich. Fachagentur Nachwachsende Rohstoffe e.V. (FNR), Gülzow. https://www.infothek-biomasse.ch/images/178_2009_FNR_ Biogasanlagen_im_Vergleich.pdf. Accessed 27 Apr 2018.

20. Angelidaki I, Treu L, Tsapekos P, Luo G, Campanaro S, Wenzel H, Kougias PG (2018) Biogas upgrading and utilization: Current status and perspectives. Biotechnol Adv 36(2):452-466. https://doi.org/10.1016/j. biotechadv.2018.01.011

21. Sun Q, Li H, Yan J, Liu L, Yu Z, Yu X (2015) Selection of appropriate biogas upgrading technology - a review of biogas cleaning, upgrading and utilisation. Renew Sust Energ Rev 51:521-532. https://doi.org/10.1016/j.rser 2015.06.029.

22. Abatzoglou N, Boivin S (2009) A review of biogas purification processes. Biofuels Bioprod Biorefin 3(1):42-71. https://doi.org/10.1002/bbb.117

23. Petersson A, Wellinger A (2009) Biogas upgrading technologies developments and innovations. IEA Bioenergy. https://www.iea-biogas.net/ files/daten-redaktion/download/publi-task37/upgrading_rz_low_final.pdf. Accessed 20 Apr 2019.

24. Hoyer K, Hulteberg C, Svensson M, Jernberg J, Nørregård Ø (2016) Biogas Upgrading - Technical Review. Energiforsk. 2016. http://vav.griffel.net/filer/C Energiforsk2016-275.pdf. Accessed 20 May 2019.

25. Awe OW, Zhao Y, Nzihou A, Minh DP, Lyczko N (2017) A review of biogas utilisation, purification and upgrading technologies. Waste Biomass Valori 8(2):267-283. https://doi.org/10.1007/s12649-016-9826-4

26. Scholwin F, Grope J, Clinkscales A, Boshell F, Saygin D, Salgado A, Seleem A (2018) Biogas for road vehicles: Technology brief, International Renewable Energy Agency (IRENA) 2018, Abu Dhabi. https://www.irena.org/-/media/ Files/IRENA/Agency/Publication/2017/Mar/IRENA_Biogas_for_Road_ Vehicles_2017.pdf. Accessed 10 March 2019.

27. Kummamuru B (2017) WBA Global Bioenergy Statistics 2017. Stockholm, Sweden: World Bioenergy Association (WBA) http://worldbioenergy.org/ uploads/WBA\%20GBS\%202017_hq.pdf Accessed 20 May 2019.

28. Moghaddam EA, Ahlgren S, Nordberg $\AA$ (2016) Assessment of novel routes of biomethane utilization in a life cycle perspective. Front Bioeng Biotechnol 4:89. https://doi.org/10.3389/fbioe.2016.00089

29. Bagi Z, Ács N, Böjti T, Kakuk B, Rákhely G, Strang O, Szuhaj M, Wirth R, Kovács KL (2017) Biomethane: The energy storage, platform chemical and greenhouse gas mitigation target. Anaerobe 46:13-22. https://doi.org/10. 1016/j.anaerobe.2017.03.001

30. Verbeeck K, Buelens LC, Galvita W, Marin GB, Van Geem KM, Rabaey K (2018) Upgrading the value of anaerobic digestion via chemical production from grid injected biomethane. Energy Environ Sci 11(7):1788-1802. https:// doi.org/10.1039/c8ee01059e

31. BioMCN (2018) http://www.biomcn.eu/ Accessed 27 Mar 2019.

32. EBA (2017) EBA (European Biogas Association) Digestate factsheet: the value of organic fertilisers for Europe's economy, society and environment. http:// european-biogas.eu/wp-content/uploads/2015/07/Digestate-paper-final08072015.pdf. Accessed 10 June 2019.

33. Holm-Nielsen JB, Al Seadi T, Oleskowicz-Popiel P (2009) The future of anaerobic digestion and biogas utilization. Bioresour Technol 100(2):54785484. https://doi.org/10.1016/j.biortech.2008.12.046

34. Dauber J, Brown C, Fernando AL, Finnan J, Krasuska E, Ponitka J, Styles D, Thrän D, Van Groenigen KJ, Weih M, Zah R (2012) Bioenergy from "surplus" land: environmental and socio-economic implications. BioRisk 7:5-50. https://doi.org/10.3897/biorisk.7.3036

35. HROTE (2018) Povlašteni proizvođači s kojima je HROTE sklopio ugovor o otkupu električne energije, a čija su postrojenja u sustavu poticanja. Electricity Purchase Agreement with Croatian Energy Market Operator (Hrvatski operator tržišta energije, HROTE), https://files.hrote.hr/files/PDF/ Sklopljeni\%20ugovori/PP_HR_14_12_2018.pdf. Accessed 15 Nov 2019.

36. Government of the Republic of Croatia (2018) Directive on the stimulation of electricity production from renewable energy sources and high-efficiency cogeneration, In: Official Gazette of the Republic of Croatia OG No. 116/ 2018 https://narodne-novine.nn.hr/clanci/sluzbeni/2018_12_116_2300.html. Accessed 27 Nov 2019

37. Đurđević D, Blecich P, Lenic K (2018) Energy potential of digestate produced by anaerobic digestion in biogas power plants: The case study of Croatia. Environ Eng Sci 35:1286-1293. https://doi.org/10.1089/ees.2018.0123

38. Kampman B, Leguijt C, Scholten T, Tallat-Kelpsaite J, Brückmann R, Maroulis G, Lesschen JP, Meesters K, Sikirica N, Elbersen B (2017) Optimal use of biogas from waste streams: an assessment of the potential of biogas from digestion in the EU beyond 2020. Research report. Luxembourg: European Commission 158. https://ec.europa.eu/energy/sites/ener/files/documents/ce_delft_3g84_ biogas_beyond_2020 final_report.pdf Accessed 27 Apr 2019.

39. Statistical Yearbook of the Republic of Croatia 2018, Chapter 16. Poljoprivreda, šumarstvo i ribarstvo/ Agriculture, forestry and fishing, pages 249-274. https://www.dzs.hr/ Accessed 15 Jan 2019. 
40. Malešević M, Jovićević Z, Štatkić S, Dolapčev S, Stojšin V (2008) Povratak ka višim i stabilnijim prinosima strnih žita, In: Zbornik naučnih radova, 14(1-2), 13-28. Radovi sa XXII savetovanja agronoma, veterinara i tehnologa, Beograd.

41. Maras I (2010) Biological yield, grain yield and protein content of modern and old winter wheat varieties. Final work. Faculty of Agriculture, University of Zagreb.

42. Kos Grabar Robina V, Havelka J, Tomšić Ž (2016) Analysis and recommendations for the establishment of biomethane production in Croatia. Conference proceedings: Mediterranean Conference on Power Generation Transmission, Distribution and Energy Conversion (MedPower 2016), Belgrade, Serbia, pp. 1-8. https://doi.org/10.1049/cp.2016.102940-1-40-8.

43. Kulišić B, Par V (2009) Agricultural potential for biogas production in Croatia. Agric Conspec Sci 74:215-220

44. Bogdanović D, Milošev D, Šeremešić S, Jug I, Đalović I (2010) Mineral nitrogen dynamic in soil of different fertility as affected by agronomic practices. Contemporary Agriculture 59(3-4):278-286

45. Filipović M, Mladenović Drinić S, Simić M, Čamdžija Z, Stevanović M, Stipešević B (2011) Postrni usevi kukuruza kao potencijalna sirovina za biogorivo. In: Zbornik apstrakata IV simpozijuma sekcije za oplemenjivanje organizama društva genetičara Srbije /Novi Sad: Društvo genetičara Srbije, Beograd, 37-38.

46. Dragičević V, Miletić M, Pavković B (2015) Investigation on possibilities for biogas production from organic waste on the Croatian island of Krk. Technical Gazette 22:755-762. https://doi.org/10.17559/TV-20150301094031.

47. Einarsson R, Persson UM (2017) Analyzing key constraints to biogas production from crop residues and manure in the EU-A spatially explicit model. PLoS One 12(1):e0171001. https://doi.org/10.1371/journal.pone. 0171001

48. WBA (2018) Bioenergy agreement as a guideline for the development of bioenergy in Croatia towards 2030. http://worldbioenergy.org/news/408/47/ WBA-signs-agreement-to-promote-bioenergy-in-Croatia. Accessed 27 May 2019.

49. Kiesel A, Lewandowski I (2017) Miscanthus as biogas substrate - cutting tolerance and potential for anaerobic digestion. GCB Bioenergy 9:153-167. https://doi.org/10.1111/gcbb.12330

50. Hadar $Y$ (2013) Sources for lignocellulosic raw materials for the production of ethanol. In: V. Faraco (ed.), Lignocellulose conversion. Springer-Verlag Berlin Heidelberg 2013. p. 21-38. https://doi.org/10.1007/978-3-64237861-4_2.

51. Bilandžija N (2014) Perspective and potential use of Miscanthus x giganteus culture in Croatia. Inženjerstvo okoliša 1(2):81-87

52. Krička T, Marin A, Bilandžija N, Jurišić V, Antonović A, Voća N, Grubor M (2017) Biomass valorisation of Arundo donax L., Miscanthus x giganetus and Sida hermaphrodita for biofuel production. Int Agrophys 31:575-581. https:// doi.org/10.1515/intag-2016-0085

53. Bilandžija N, Jurišić V, Voća N, Leto J, Matin A, Grubor M, Krička T (2017) Energy valorization of Miscanthus x giganteus biomass: a case study in Croatia. Journal on Processing and Energy in Agriculture 21(1):32-36

54. Dundović J, Krička T (2007) Energetska uporaba šumske i poljoprivredne biomase u Republici Hrvatskoj. In: Matić S (ed) Zbornik radova znanstvenog skupa: Poljoprivreda i šumarstvo kao proizvođači obnovljivih izvora energije. Hrvatska akademija znanosti i umjetnosti, Zagreb, pp 53-61

55. Ištvanić J, Antonović A, Greger K, Pervan S, Jambreković V, Benković Z, Kavran M (2008) Sawmilling in Croatia Part 1 - Historical review of Croatian sawmilling. Drvna industrija: Znanstveni časopis za pitanja drvne tehnologije 59(3):121-130

56. Fantozzi F, Buratti C (2009) Biogas production from different substrates in an experimental continuously stirred tank reactor anaerobic digester. Bioresour Technol 100:5783-5789. https://doi.org/10.1016/j.biortech.2009.06.013

57. Pukšec T, Duić N (2012) Economic viability and geographic distribution of centralized biogas plants: case study Croatia. Clean Techn Environ Policy 14: 427-433. https://doi.org/10.1007/s10098-012-0460-y

58. Bilandžija N, Voća N, Krička T, Jurišić V, Matin A (2013) Biogas production on dairy farms: A Croatia case study. Mjekarstvo 63:22-29

59. Cook MT, Hayball PJ, Hutchinson W, Nowak BF, Hayball JD (2003) Administration of a commercial immunostimulant preparation, EcoActiva ${ }^{\text {TM }}$ as a feed supplement enhances macrophage respiratory burst and the growth rate of snapper (Pagrus auratus, Sparidae (Bloch and Schneider)) in winter. Fish Shellfish Immun 14(4):333-345

60. Government of the Republic of Croatia (2017) Decision on the adoption of the waste management plan of the Republic of Croatia for the period 2017-
2022. In: Official Gazette of the Republic of Croatia OG No. 3/2017. https:// www.mzoip.hr/doc/management_plan_of_the_republic_of_croatia_for_ the_period_2017-2022.pdf. Accessed 27 May 2019.

61. Government of the Republic of Croatia (2015) Act on renewable energy sources and high-efficiency cogeneration In: Official Gazette of the Republic of Croatia OG No. 100/2015. https://narodne-novine.nn.hr/clanci/sluzbeni/2 015_09_100_1937.html Accessed 28 Nov 2019.

62. Jelavić V , Bišćan M, Marković B, Horvatić Viduka E, Tomac V, Kos R, Masnjak B, et al. (2019) Strateška studija procjene utjecaja na okoliš za strategiju energetskog razvoja Republike Hrvatske do 2030. godine s pogledom na 2050.godinu Treća inačica. https://mzoe.gov.hr/UserDocsImages/Uprava za energetiku/Strategije, planovi i programi/Strateška studija procjene utjecaja na okoliš za Strategiju energetskog razvoja RH do 2030 s pogledom na 2050.god.-Treća inačica.pdf. Accessed December 10th 2019.

63. Wolf Theiss (2016) Wolf Theiss guide to waste to energy in Central, Eastern \& Southeastern Europe. WOLF THEISS Rechtsanwälte GmbH \& Co KG, Attorneys-at-Law Schubertring 6, 1010 Vienna, Austria. www.wolftheiss.com. Accessed 27 Mar 2019

\section{Publisher's Note}

Springer Nature remains neutral with regard to jurisdictional claims in published maps and institutional affiliations.
Ready to submit your research? Choose BMC and benefit from:

- fast, convenient online submission

- thorough peer review by experienced researchers in your field

- rapid publication on acceptance

- support for research data, including large and complex data types

- gold Open Access which fosters wider collaboration and increased citations

- maximum visibility for your research: over $100 \mathrm{M}$ website views per year

At BMC, research is always in progress.

Learn more biomedcentral.com/submissions 